\title{
Multiplication of blueberry mini-cuttings in different growth media
}

\author{
Renata Koyama $^{1, *}$, Adriane Marinho de Assis ${ }^{2}$, Wellington Fernando Silva Borges ${ }^{1}$, Lilian Yukari Yamamoto ${ }^{1}$, \\ Ronan Carlos Colombo ${ }^{1}$, Douglas Mariani Zeffa ${ }^{1}$, Luciane Gomes Barros ${ }^{1}$, Beatriz Barreira ${ }^{1}$, Ibrar Hussain ${ }^{1}$, \\ Muhammad Shahab ${ }^{1}$, Saeed Ahmed ${ }^{1}$ and Sergio Ruffo Roberto ${ }^{1}$
}

${ }^{1}$ Universidade Estadual de Londrina, Departamento de Agronomia, CP 6001, CEP 86051-970, Londrina, PR, Brazil. ${ }^{2}$ Universidade Federal de Pelotas, Departamento de Fitotecnia, CP 354, CEP 96010-900, Pelotas, RS, Brazil. *Corresponding author, E-mail: emykoyama@hotmail.com.

\begin{abstract}
The objective of this study was to evaluate the influence of length of herbaceous cuttings and substrates on the multiplication of 'Woodard' and 'Briteblue' blueberry cuttings. The experimental design was entirely randomized. Four replicates of 10 cuttings per plot in a $3 \times 2$ factorial arrangement, three cutting lengths $(5,8$, and $12 \mathrm{~cm}$ ) and two types of substrate (rice hull ash and coconut fiber) were evaluated. The cuttings were collected in two seasons: summer and fall. After the cuttings were prepared, they were placed in perforated plastic boxes containing each substrate for rooting, which were placed in a mist chamber under intermittent mist. After 158 days, the following variables were evaluated: proportion of rooted cuttings, cutting survival, leaf retention, number of roots per cutting, root mean length, root dry mass, unrooted cuttings with callus, and the proportion of sprouting cuttings. The use of 5 -cm herbaceous cuttings collected in the summer and grown in rice hull optimizes the multiplication of 'Woodard' and 'Briteblue' blueberry cuttings.
\end{abstract}

Key words: Vegetative propagation, Vaccinium sp., herbaceous cuttings.

\section{INTRODUCTION}

Blueberry (Vaccinium sp.) is a temperate fruit tree with great economic importance in several countries. Known as a "fountain of youth" due to its nutritional composition, blueberry has shown an increase in commercialization of both its fruits and derivatives. Blueberry cultivation is booming in South American countries, largely influenced by off-season demand of the United States and of some European countries. These market demands create business opportunities for the Brazilian productive sector due to the fact that this species is highly profitable and adaptable to low-input production systems (Hoffmann et al., 1995; Santos and Raseira 2002).

Blueberry propagation can be performed by seeds, grafting, and cuttings, with this last method being the most commonly used (Raseira and Antunes 2004). However, rooting can vary according to the cultivar (Fisher et al., 2008; Peña et al., 2012; Vignolo et al., 2012), to the substrate used (Pelizza et al., 2011; Ristow et al., 2012), and to the season in which cuttings are collected (Marangon and Biasi 2013).

Cuttings of 10 to $20 \mathrm{~cm}$ in length are generally used in the production of blueberry seedlings by cuttings, keeping 2 to 3 upper leaves and removing the rest (Antunes 2006). However, shorter cuttings can provide better use of branches and reduce harm to the stock trees, particularly when it is necessary to obtain high numbers of cuttings and especially in collections made up of few trees of the same variety (Oliveira et al., 2003).

Mini-cutting is considered a specialization of conventional cutting. It consists of the use of plant shoots propagated via cuttings, or seedlings produced by seeds between 3 and $5 \mathrm{~cm}$, with leaves and buds (Pelizza et al., 2010). In fruiting species, such as yellow passion and plum, the use of mini-cuttings has been shown to be viable (Tonietto et al., 2001; Carvalho et al., 2007; Ferriani et al., 2010). In addition, some studies have shown that softwood cuttings of blueberry plants could be commercially more viable than other propagation techniques. Micro-propagation facilities are expensive, and require skilled operators for success. Aside from the high setup costs, one of the most commonly cited disadvantages of micro-propagation is the production of genetic variants, or plants that look and behave differently from the parent (Miller et al., 2006).

One of the major limitations for crop establishment is the difficulty of cutting rooting and seedling development in the field. The substrate is important in the initial development of blueberry seedlings as a result of the very shallow blueberry root system, with fine roots sensitive to compaction and poor drainage (Santos and Raseira 2002; Ristow et al., 2010).

For the reason that they constitute waste materials of agricultural production, rice hull ash and coconut fiber are among the possible substrates for the rooting of cuttings. Rice hull ash is a sterile substrate, thanks to the carbonization process, and enables good aeration, drainage, and air exchange at the base of the roots. Coconut fiber has been pointed out as an agricultural substrate due to its advantageous physical structure, providing high porosity and high potential for moisture retention, as well as for being biodegradable (Lone et al., 2010).

The objective of this study was to evaluate the effect of different cutting lengths and substrates on the rooting of herbaceous cuttings of 'Woodard' and 'Briteblue' blueberry cultivars to optimize the nursery production system. 


\section{MATERIALS AND METHODS}

The experiment was conducted from April to September 2013 and from January to July 2014 at Londrina State University (Universidade Estadual de Londrina, UEL), State of Paraná (PR), Brazil (latitude $23^{\circ} 23^{\prime}$ S, longitude $51^{\circ} 11^{\prime} \mathrm{W}$, altitude $566 \mathrm{~m}$ ). Herbaceous cuttings were taken from the central part of stock tree branches of Vaccinium sp. 'Woodard' and 'Briteblue' kept in a greenhouse at the same institution, derived from the collection of blueberry cultivars belonging to Embrapa Temperate Climate (Embrapa Clima Temperado), Pelotas, State of Rio Grande do Sul (RS).

The experimental design was entirely randomized, with four replicates of 10 cuttings per plot in a $3 \times 2$ factorial arrangement, using three cutting lengths $(5,8$, and $12 \mathrm{~cm}$ ) and 2 substrates (rice hull ash and standard coconut fiber - Golden Mix $47^{\circledR}$ ) as factors (Figure 1A).

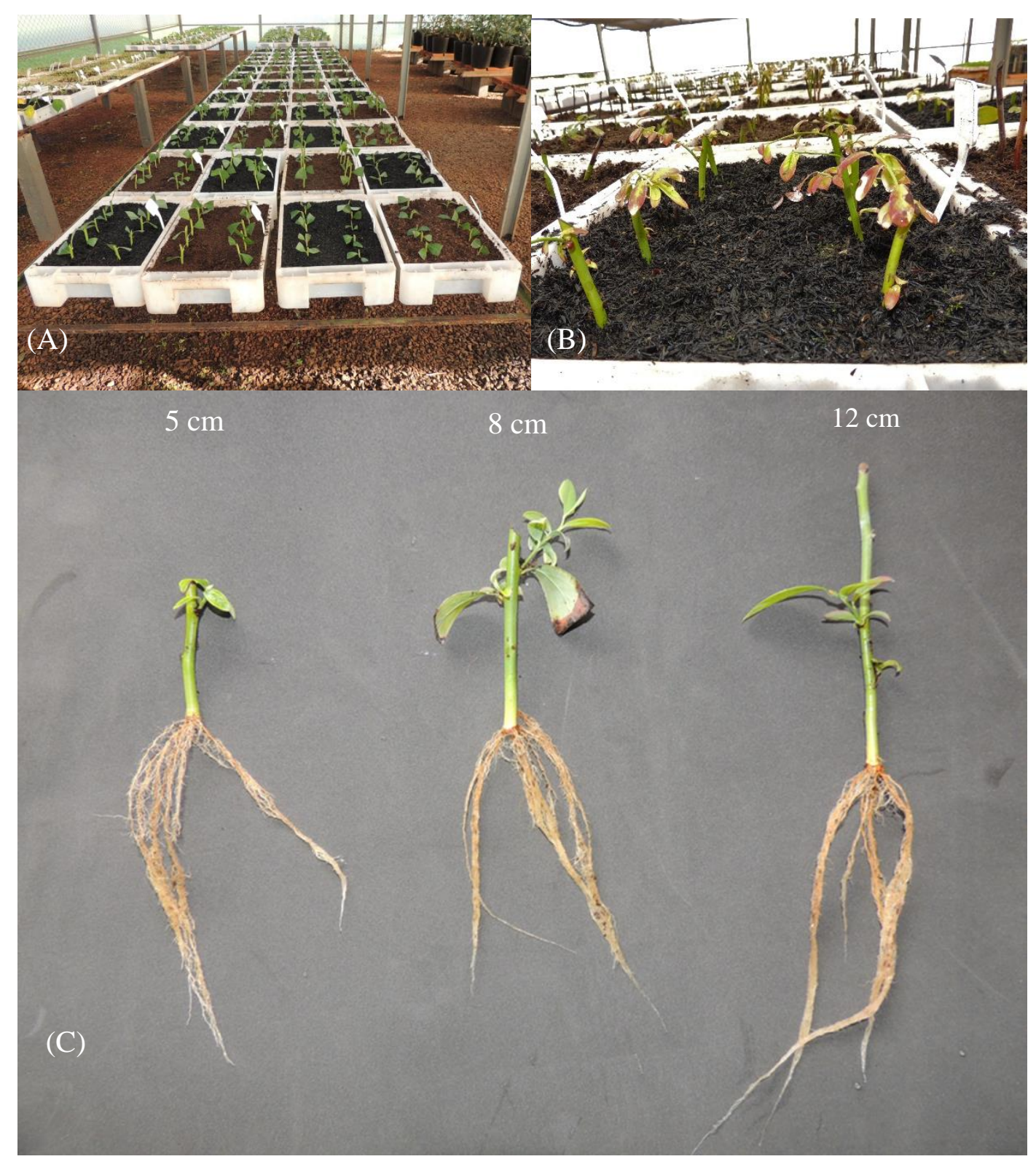

Figure 1. Pictures showing A. Experimental area, B. Bud sprouting, C. Rooted cuttings of 'Woodard' blueberry.

The preparation of the cuttings consisted of a bevel cut just below a node, with the elimination of leaves from the bottom portion, maintaining 2 pairs of leaves on the top portion cut in half to avoid excessive transpiration. During preparation, the cuttings were placed in a container with water to avoid dehydration. Then, the bases of the mini-cuttings were immersed into a growth regulator solution (IBA) at $1000 \mathrm{mg} \mathrm{L}^{-1}$ diluted inethilic alcohol 50\%, for 10 seconds. After that, the cuttings were placed in perforated plastic boxes $(44 \times 30 \times 7 \mathrm{~cm})$ containing the substrates for rooting and then placed in a mist chamber with intermittent mist controlled by a timer and a solenoid valve. The valve was programmed to spray for 10 seconds every 6 minutes. The spray nozzle used (Model Mist DanSprinklers, Israel) has a flow rate of $35 \mathrm{~L} \mathrm{hour}^{-1}$. The mist chamber was located in a greenhouse 
with transparent polyethylene film cover and 30\% shade mash. The average temperature during April until September 2013 was $20^{\circ} \mathrm{C}$ with $69 \%$ of relative humidity and from January to July 2014 , the average temperature was $24^{\circ} \mathrm{C}$ with $76 \%$ of relative humidity.

The experiments were evaluated identically in 2 periods of the year, that is, using cuttings collected in the fall of 2013 (mid-April) and in the summer of 2014 (mid-January).

For fungal disease control, the cuttings were treated weekly by spraying them with tebuconazole-based fungicides $\left(1 \mathrm{~mL} \mathrm{~L}^{-1}\right)$. Every 15 days, foliar fertilization was applied by spraying with Biofert Plus ${ }^{\circledR}(8-9-9+$ micronutrients) fertilizer at concentration of $5 \mathrm{~mL} \mathrm{~L}^{-1}$.

At 158 days after setting up the experiments, the following variables were evaluated: proportion of rooted cuttings ( $\%$ of cuttings that put forth at least one root); cutting survival ( $\%$ of live cuttings); leaf retention (\% of cuttings that did not lose their leaves); number of roots per cutting; mean length of roots per cutting (cm); root dry mass per cutting (g); cuttings with callus (\% of live cuttings without roots); and proportion of sprouting cuttings (\%). The root dry mass was obtained by drying in a forced air oven at $78^{\circ} \mathrm{C}$ until no change of the dry weight was observed.

Earlier to individual analysis of variance, the homoscedasticity and normality of the residues were confirmed using Bartlett (1987) $(\mathrm{p} \leq 0.05)$ and Lilliefors $(1967)$ tests $(\mathrm{p} \leq 0.05)$, respectively. Characteristics which were not in line with these assumptions were transformed into $\sqrt{ }(\mathrm{x} / 100)$ or $\sqrt{ }(\mathrm{x}+1)$, depending on the characteristic. After performing the individual analysis of variance, those characteristics which had less than seven ratios, between the highest and the lowest residuals, were submitted to factorial analysis of variance. Means of significantly affected characteristics were compared by Tukey`s test $(p \leq 0.05)$. Genes program was used for statistical analysis of the data (Cruz 2013).

\section{RESULTS AND DISCUSSION}

There was a significant interaction between different cutting lengths and substrates just for the percentage of rooted cuttings, cutting survival, leaf retention, root dry mass per cutting, and proportion of sprouted cuttings of the 'Woodard' cultivar collected in the summer, with the evaluated factors acting independently from the other variables (Table 1).

Table 1. Mean values of rooted cuttings percentage, cutting survival percentage, leaf retention percentage, root dry mass per cutting and sprouted cuttings percentage of 'Woodard' blueberry collected in the summer. Londrina. 2014.

\begin{tabular}{|c|c|c|c|c|c|c|c|c|c|c|}
\hline \multirow{2}{*}{$\begin{array}{l}\text { Cuttig } \\
\text { length } \\
(\mathrm{cm})\end{array}$} & \multicolumn{2}{|c|}{$\begin{array}{l}\text { Rooted cuttings } \\
\qquad(\%)\end{array}$} & \multicolumn{2}{|c|}{$\begin{array}{l}\text { Cutting survival } \\
(\%)\end{array}$} & \multicolumn{2}{|c|}{ Leaf retention $(\%)$} & \multicolumn{2}{|c|}{$\begin{array}{l}\text { Root dry mass per } \\
\text { cutting } \\
(\mathrm{g})\end{array}$} & \multicolumn{2}{|c|}{$\begin{array}{l}\text { Sprouted cuttings } \\
\qquad(\%)\end{array}$} \\
\hline & RHA & $\mathrm{CF}$ & RHA & $\mathrm{CF}$ & RHA & $\mathrm{CF}$ & RHA & $\mathrm{CF}$ & RHA & $\mathrm{CF}$ \\
\hline 5 & $80.0 \mathrm{aA}^{*}$ & $17.5 \mathrm{aB}$ & $90.0 \mathrm{aA}$ & $52.5 \mathrm{aB}$ & $85.0 \mathrm{aA}$ & $32.5 \mathrm{aB}$ & $0.428 \mathrm{aA}$ & $0.140 \mathrm{aB}$ & $77.5 \mathrm{aA}$ & $10,0 \mathrm{aB}$ \\
\hline 8 & $25.0 \mathrm{bA}$ & $7.5 \mathrm{aA}$ & $60.0 \mathrm{bA}$ & $47.5 \mathrm{aA}$ & $25.0 \mathrm{bA}$ & $30.0 \mathrm{aA}$ & $0.080 \mathrm{bA}$ & $0.123 \mathrm{aA}$ & $32.5 \mathrm{bA}$ & $7.5 \mathrm{aB}$ \\
\hline 12 & $20.0 \mathrm{bA}$ & $2.5 \mathrm{aA}$ & $22.5 \mathrm{cA}$ & $32.5 \mathrm{bA}$ & $10.0 \mathrm{bA}$ & $0.0 \mathrm{bA}$ & $0.095 \mathrm{bA}$ & $0.012 \mathrm{aA}$ & $15.0 \mathrm{bA}$ & $2.5 \mathrm{aA}$ \\
\hline $\mathrm{CV}(\%)$ & & & & & & & & & & \\
\hline
\end{tabular}

*Means followed by the same letters in columns do not differ according to Tukey's test $(p<0.05)$. ${ }^{\text {ns }}$ not significant. RHA: Rice hull ash; CF: Coconut fiber.

Herbaceous cuttings $5 \mathrm{~cm}$ in length of 'Woodard' grown in rice hull ash showed a higher percentage of rooting $(80 \%)$ compared to $12-\mathrm{cm}$ cuttings $(20 \%)$ (Table 1$)$. The high percentage of rooting observed in this study was greater than that described by Wagner Junior et al. (2004), who evaluated the same cultivar obtaining 54\% rooted cuttings, used cutting $12 \mathrm{~cm}$ in length growing in a sand substrate and collected in the summer. Shorter cuttings have less surface area exposed to the environment, and therefore, the demand for water to supply living tissues is reduced during the multiplication of these cuttings (Lima et al., 2006).

The 5-cm 'Woodard' cuttings grown in rice hull ash also showed a higher percentage of survival compared to the 12-cm cuttings (90 and $22.5 \%$, respectively). The same was observed for the cuttings grown in coconut fiber, for which the $5-\mathrm{cm}$ cuttings resulted in $52.5 \%$ survival, while the 12 -cm cuttings exhibited $32.5 \%$ survival (Table 1). These results corroborate those of Lima et al. (2006), who evaluated different lengths of cuttings of Barbados cherry, concluding that 10-cm cuttings taken from the central portion of branches were more suitable showing higher survival than cuttings 15 or $20 \mathrm{~cm}$ in length. 
The highest percentage of cuttings with leaf retention and sprouting (Figure 1B) seems to have contributed to rooting in rice hull ash owing to the 5-cm cuttings. They showed higher root dry mass per cutting $(0.428$ g) compared to the 8 and $12-\mathrm{cm}$ cuttings ( 0.08 and $0.09 \mathrm{~g}$, respectively) (Table 1). According to Xavier et al. (2009), the presence of leaves on cuttings is essential for the formation of new roots. This is due to the fact that leaves are sources of auxins and carbohydrates, reducing the time required for rooting and, consequently, diminishing death of cuttings due to dehydration.

In an experiment conducted with 'Climax' blueberry in different substrates, the low rooting percentage of the cuttings (1.3\%) was attributed to high levels of defoliation (Hoffmann et al., 1995). Studying blueberry rooting in different seasons with application of indolebutyric acid and heated substrate, Marangon and Biasi (2013) demonstrated that the 'Bluegem' and 'Powderblue' cultivars are influenced by the cutting collection season, with the best results obtained in the summer, the period of greatest leaf retention.

There was no significant difference among the treatments for the 'Woodard' cuttings collected in the summer with regards to the number and length of roots per cutting (Figure 1C) and the percentage of cuttings with callus (Table 2). Similarly, the cuttings collected in the fall did not differ regarding the percentage of rooted cuttings, survival, number of roots per cutting, and proportions of cuttings with sprouting and callus (Table 3).

The 'Woodard' cuttings rooted in coconut fiber in the fall showed greater leaf retention, higher mean root length, and a higher mean root dry mass per cutting compared to those grown in rice hull ash, regardless of their length (Table 3). Such results are likely a consequence of higher water retention of coconut fiber in comparison to rice hull ash (Yamamoto et al., 2013), which may have contributed to greater leaf attachment and root development. Herbaceous cuttings have more tender tissues, requiring substrates with relatively high humidity to supply the water lost through the leaves (Silva et al., 2011).

Exposing cuttings to adverse environmental conditions can cause their death due to tissue dehydration, mainly in species with difficult rooting, such as blueberry (Trevisan et al., 2008). In the fall, trees prepare for dormancy, having low levels of activity in young tissues of secondary phloem, vascular vessels, and cambium. They also present greater accumulation of phenols and inhibitors, leading to a slower formation of the root system of the cuttings (Hoffmann et al., 1995, Martini et al., 2013). Thus, the correct choice of substrate becomes important for the initial development of cuttings (Santos and Raseira 2002).

The 'Briteblue' blueberry cuttings rooted in rice hull ash in the summer presented better results for the percentage of rooted cuttings, survival, leaf retention, number of roots per cutting, mean root length, root dry mass per cutting and proportion of sprouting cuttings compared to those grown in coconut fiber. The $5-\mathrm{cm}$ cuttings had higher survival and leaf retention, regardless of substrate (Table 4). In an experiment developed with 'Climax' blueberry micro-cuttings, Pelizza et al. (2011) found higher percentages of survival, number of leaves, and rooting in substrate composed of PlantMax ${ }^{\circledR}$ and rice hull ash. The authors also attributed the cutting collection season (summer) to the higher percentage of rooting due to the fact that, in temperate perennial trees, endogenous auxin levels vary with the season, with higher concentrations in spring and summer than those observed in fall and winter.

Rice hull ash is a substrate with high aeration, low density, high water permeability, and high resistance to decomposition, without the risk of oxygen lack for roots (Kämpf et al., 2006). Moreover, Antunes (2006) reported that many substrates can be used for blueberry seedling production; however, the most appropriate substrates are those with good aeration and drainage.

Table 2. Mean values for number of roots per cutting, root length, and percentage of cuttings with callus of 'Woodard' blueberry collected in the summer. Londrina. 2014.

\begin{tabular}{lccc}
\hline Cutting length $(\mathrm{cm})$ & $\begin{array}{c}\text { Number of roots per } \\
\text { cutting }\end{array}$ & $\begin{array}{c}\text { Root length } \\
(\mathrm{cm})\end{array}$ & $\begin{array}{c}\text { Cuttings with callus } \\
(\%)\end{array}$ \\
\hline 5 & $3.5^{\mathrm{ns}}$ & $7.2^{\mathrm{ns}}$ & $5.0^{\mathrm{ns}}$ \\
8 & 3.0 & 6.7 & 1.3 \\
12 & 2.5 & 2.8 & 1.3 \\
\hline wth medium & & & $4.2^{\mathrm{ns}}$ \\
\hline RHA & $3.7^{\mathrm{ns}}$ & $6.5^{\mathrm{ns}}$ & 0.8 \\
$\mathrm{CF}$ & 2.3 & 4.6 & 18.14 \\
\hline $\mathrm{CV}(\%)$ & 34.91 & 38.92 & \\
\hline
\end{tabular}

${ }^{\mathrm{ns}}$ not significant. RHA: Rice hull ash; CF: Coconut fiber. 
Table 3. Mean values of rooted cuttings percentage, cutting survival percentage, leaf retention percentage, number of roots per cutting, root length, root dry mass per cutting, percentage of cuttings with callus, and sprouted cuttings percentage of 'Woodard' blueberry collected in the fall. Londrina. 2014.

\begin{tabular}{lcccccccc}
\hline $\begin{array}{l}\text { Cutting } \\
\text { length }(\mathrm{cm})\end{array}$ & $\begin{array}{c}\text { Rooted } \\
\text { cuttings } \\
(\%)\end{array}$ & $\begin{array}{c}\text { Cuttin } \\
\text { surviv } \\
\text { al } \\
(\%)\end{array}$ & $\begin{array}{c}\text { Leaf } \\
\text { retentio } \\
\mathrm{n}(\%)\end{array}$ & $\begin{array}{c}\text { Number } \\
\text { of roots } \\
\text { per cutting }\end{array}$ & $\begin{array}{c}\text { Mean } \\
\text { root } \\
\text { length } \\
(\mathrm{cm})\end{array}$ & $\begin{array}{c}\text { Root dry } \\
\text { mass per } \\
\text { cutting } \\
(\mathrm{g})\end{array}$ & $\begin{array}{c}\text { Cutting } \\
\text { s with } \\
\text { callus } \\
(\%)\end{array}$ & $\begin{array}{c}\text { Sprouted } \\
\text { cuttings } \\
(\%)\end{array}$ \\
\hline 5 & $27.5^{\text {ns }}$ & $67.5^{\text {ns }}$ & $15.0^{\text {ns }}$ & $2.3^{\text {ns }}$ & $6.4^{\text {ns }}$ & $0.038^{\text {ns }}$ & $26.2^{\text {ns }}$ & $40.0^{\text {ns }}$ \\
8 & 21.3 & 56.3 & 11.3 & 3.0 & 4.8 & 0.045 & 17.5 & 28.8 \\
12 & 29.5 & 52.5 & 11.3 & 3.7 & 6.4 & 0.046 & 14.4 & 35.4 \\
\hline Substrate & & & & & & & & \\
\hline RHA & $19.2^{\text {ns }}$ & $50.0^{\text {ns }}$ & $4.2 \mathrm{~b}$ & $1.5^{\text {ns }}$ & $2.9 \mathrm{~b}$ & $0.008 \mathrm{~b}$ & $23.3^{\text {ns }}$ & $40.8^{\text {ns }}$ \\
CF & 33.0 & 67.5 & $20.8 \mathrm{a}$ & 4.4 & $8.7 \mathrm{a}$ & $0.078 \mathrm{a}$ & 15.4 & 28.6 \\
\hline CV $(\%)$ & 34.11 & 22.46 & 31.45 & 36.35 & 28.10 & 14.30 & 21.19 & 31.46 \\
\hline
\end{tabular}

Means followed by the same letters in columns do not differ according to Tukey's test $(p<0.05)$. ${ }^{\text {ns }}$ not significant. RHA: Rice hull ash; CF: Coconut fiber.

Table 4. Mean values of rooted cuttings percentage, cutting survival percentage, leaf retention percentage, number of roots per cutting, root length, root dry mass per cutting, percentage of cuttings with callus, and sprouted cuttings percentage of 'Briteblue' blueberry collected in the summer. Londrina. 2014.

\begin{tabular}{|c|c|c|c|c|c|c|c|c|}
\hline $\begin{array}{l}\text { Cutting length } \\
(\mathrm{cm})\end{array}$ & $\begin{array}{c}\text { Rooted } \\
\text { cuttings } \\
(\%)\end{array}$ & $\begin{array}{c}\text { Cutting } \\
\text { survival } \\
(\%)\end{array}$ & $\begin{array}{l}\text { Leaf } \\
\text { retention } \\
(\%)\end{array}$ & $\begin{array}{c}\text { Number } \\
\text { of roots } \\
\text { per } \\
\text { cutting }\end{array}$ & $\begin{array}{l}\text { Mean root } \\
\text { length } \\
(\mathrm{cm})\end{array}$ & $\begin{array}{l}\text { Root dry } \\
\text { mass per } \\
\text { cutting } \\
(\mathrm{g})\end{array}$ & $\begin{array}{l}\text { Cuttings } \\
\text { with } \\
\text { callus } \\
(\%)\end{array}$ & $\begin{array}{c}\text { Sprouted } \\
\text { cuttings } \\
(\%)\end{array}$ \\
\hline 5 & $47.5^{\mathrm{ns}}$ & $76.3 \mathrm{a}$ & $70.0 \mathrm{a}$ & $3.7^{\mathrm{ns}}$ & $6.7^{\mathrm{ns}}$ & $0.272^{\mathrm{ns}}$ & $5.0^{\mathrm{ns}}$ & $38.8^{\mathrm{ns}}$ \\
\hline 8 & 27.5 & $43.8 \mathrm{~b}$ & $28.8 \mathrm{~b}$ & 3.3 & 5.2 & 0.147 & 3.8 & 22.5 \\
\hline 12 & 38.8 & $61.3 \mathrm{ab}$ & $13.8 \mathrm{~b}$ & 6.7 & 12.3 & 0.148 & 1.3 & 42.5 \\
\hline \multicolumn{9}{|l|}{ Substrate } \\
\hline RHA & $62.5 \mathrm{a}$ & $78.3 \mathrm{a}$ & $50.0 \mathrm{a}$ & $7.7 \mathrm{a}$ & $12.7 \mathrm{a}$ & $0.284 \mathrm{a}$ & $5.8^{\mathrm{ns}}$ & $62.5 \mathrm{a}$ \\
\hline $\mathrm{CF}$ & $13.3 \mathrm{~b}$ & $42.5 \mathrm{~b}$ & $25.0 \mathrm{~b}$ & $1.5 \mathrm{~b}$ & $3.4 \mathrm{~b}$ & $0.094 \mathrm{~b}$ & 0.8 & $6.7 \mathrm{~b}$ \\
\hline $\mathrm{CV}(\%)$ & 35.02 & 29.84 & 32.43 & 39.45 & 30.32 & 9.51 & 22.25 & 38.86 \\
\hline
\end{tabular}

Means followed by the same letters in columns do not differ according to Tukey's test $(p<0.05)$. ${ }^{\text {ns }}$ not significant. RHA: Rice hull ash; CF: Coconut fiber.

Rice hull ash allowed for higher survival and proportions of cuttings with sprouting and calluses for 'Briteblue' collected in the fall (Table 5). Evaluating cuttings of the ornamental tree Japanese Stewartia, Wilson and Struve (2004) observed that the growth of sprouts reduced cutting mortality during the winter by increasing the levels of structural carbohydrates. Nevertheless, when vigorous sprouting of buds occurs on the upper part of cuttings, these buds can inhibit rooting because of an increase in cambial activity, thus slowing rooting. This pattern is shown by the means obtained for the number of roots, mean length, and root dry mass, which were lower for the cuttings grown in rice hull ash compared to those rooted in coconut fiber.

Significant differences among cutting lengths were not found, except for the variable mean length of roots, which was higher for the 5-cm 'Briteblue' cuttings collected in the fall (Table 5), with no difference between the two larger cuttings. This confirmed that the use of smaller cuttings is viable, allowing better use of the stock tree (Oliveira et al., 2003; Fisher et al., 2013). 
Table 5. Mean values of rooted cuttings, cutting survival percentage, leaf retention percentage, number of roots per cutting, root length, root dry mass per cutting, percentage of cuttings with callus, and sprouted cuttings percentage of 'Briteblue' blueberry collected in the fall. Londrina. 2014.

\begin{tabular}{|c|c|c|c|c|c|c|c|c|}
\hline $\begin{array}{l}\text { Cutting length } \\
(\mathrm{cm})\end{array}$ & $\begin{array}{c}\text { Rooted } \\
\text { cuttings } \\
(\%)\end{array}$ & $\begin{array}{c}\text { Cutting } \\
\text { survival } \\
(\%)\end{array}$ & $\begin{array}{l}\text { Leaf } \\
\text { retention } \\
\quad(\%)\end{array}$ & $\begin{array}{l}\text { Numbe } \\
\text { r of } \\
\text { roots } \\
\text { per } \\
\text { cutting }\end{array}$ & $\begin{array}{c}\text { Mean root } \\
\text { length } \\
(\mathrm{cm})\end{array}$ & $\begin{array}{l}\text { Root dry } \\
\text { mass per } \\
\text { cutting } \\
(\mathrm{g})\end{array}$ & $\begin{array}{l}\text { Cuttings } \\
\text { with } \\
\text { callus } \\
(\%)\end{array}$ & $\begin{array}{l}\text { Sprouted } \\
\text { cuttings } \\
(\%)\end{array}$ \\
\hline 5 & $40.0^{\mathrm{ns}}$ & $58.8^{\mathrm{ns}}$ & $28.8^{\mathrm{ns}}$ & $4.1^{\mathrm{ns}}$ & $8.1 \mathrm{a}$ & $0.142^{\mathrm{ns}}$ & $8.8^{\mathrm{ns}}$ & $42.5^{\mathrm{ns}}$ \\
\hline 8 & 31.3 & 61.3 & 11.3 & 3.3 & $5.2 \mathrm{ab}$ & 0.126 & 17.5 & 47.5 \\
\hline 12 & 32.5 & 48.8 & 13.8 & 4.4 & $4.7 \mathrm{~b}$ & 0.072 & 6.3 & 35.0 \\
\hline \multicolumn{9}{|l|}{ Substrate } \\
\hline RHA & $41.7^{\mathrm{ns}}$ & $73.3 \mathrm{a}$ & $20.0^{\mathrm{ns}}$ & $2.2 \mathrm{~b}$ & $3.4 \mathrm{~b}$ & $0.044 \mathrm{~b}$ & $18.3 \mathrm{a}$ & $60.0 \mathrm{a}$ \\
\hline $\mathrm{CF}$ & 27.5 & $39.2 \mathrm{~b}$ & 15.8 & $5.7 \mathrm{a}$ & $8.5 \mathrm{a}$ & 0.183 a & $3.3 \mathrm{~b}$ & $23.3 \mathrm{~b}$ \\
\hline $\mathrm{CV}(\%)$ & 31.92 & 23.11 & 34.13 & 33.95 & 34.55 & 11.41 & 24.27 & 32.90 \\
\hline
\end{tabular}

Means followed by the same letters in columns do not differ according to Tukey's test $(p<0.05)$. ${ }^{\text {ns }}$ not significant.

RHA: ice hull ash; CF: Coconut fiber.

\section{CONCLUSION}

Cuttings $5 \mathrm{~cm}$ in length rooted in rice hull ash and collected in the summer are most suitable for the multiplication of 'Woodard' and 'Briteblue' blueberries.

\section{REFERENCES}

Antunes LEC. Introdução (2006) Raseira MC, Antunes LEC Cultivo do mirtilo (Vaccinium sp). Technical communication, 8. Embrapa Clima Temperado, Pelotas, p.13-16.

Bartlett MS (1987) Properties of Sufficiency and Statistical Tests. Proceedings of the Royal Society of London. Series A, Mathematical and Physical Sciences 160 (901): 268-282.

Carvalho RI, Silva ID and Faquim R (2007) Enraizamento de miniestacas herbáceas de maracujazeiro amarelo. Semina 28 (3): 387-392.

Cruz CD (2013) GENES - a software package for analysis in experimental statistics and quantitative genetics. Acta Scientiarum 35 (3): 271-276.

Ferriani AP, Zuffellato-Ribas KC and Wendling I (2010) Miniestaquia aplicada a espécies florestais. Revista Agroambiente 4(2):102-109.

Fisher DLO, Fachinello JC, Antunes LEC, Timm CRF, Giacobbo CL (2008) Enraizamento de estacas semilenhosas de mirtilo sob o efeito de diferentes concentrações de ácido indolbutírico. Revista Brasileira de Fruticultura 30(2): 557-559.

Fischer DO, Lobato D, Fachinello JC, Corrêa LE, Fischer C and Giacobbo CL (2013) Rooting of blueberry minicuttings. Revista de la Facultad de Agronomía 112: 1-5.

Hoffmann A, Fachinello JC, Santos AM (1995) Enraizamento de estacas de duas cultivares de mirtilo (Vaccinium ashei reade) em diferentes substrates. Revista Brasileira de Agrociência 1(1): 7-11.

Wagner Júnior A, Couto M and Raseira MCB, Franzon RC (2004) Efeito da lesão basal e do ácido indolbutírico no enraizamento de estacas herbáceas de quatro cultivares de mirtilo. Revista Brasileira de Agrociência 10 (2): 251-253. 
Kämpf NA, Takane RJ and Siqueira PTV (2006) Floricultura: Técnicas de preparo de substratos. LK Editora and Comunicação, Brasília,132p.

Lilliefors HW (1967) On the Kolmogorov-Smirnov test for normality. Great Britain: Biometrika 62 (3): 399-402.

Lima RLS, Siqueira DL, Weber OB and Cazetta JO (2006) Comprimento de estacas e parte do ramo na formação de mudas de aceroleira. Revista Brasileira de Fruticultura 28(1): 83-86.

Lone AB, López EL, Rovaris SRS, Klesener DF, Higashibara L, Ataíde LT and Roberto SR (2010) Efeito do AIB no enraizamento de estacas herbáceas do porta-enxerto de videira VR 43-43 em diferentes substratos. Semina 31(3): 599-604.

Marangon AM and Biasi LA (2013) Estaquia de mirtilo nas estações do ano com ácido indolbutírico e aquecimento do substrato. Pesquisa Agropecuária Brasileira 48(1): 25-32.

Martini A, Biondi D and Natal CM (2013) Propagação por estacas de rizoma de Aspilia montevidensis (Spreng.) Kuntze. Semina 34(1): 201-208.

Miller SA, Rawnsley EK, George J and Patel N (2006) A comparison of blueberry propagation techniques used in New Zealand. Acta Horticulturae 715: 397-402.

Oliveira AF, Pasqual M, Chalfun NNJ, Regina MA and Rincón CDR (2003) Enraizamento de estacas semilenhosas de oliveira sob efeito de diferentes épocas, substratos e concentrações de ácido indolbutírico. Ciência e Agrotecnologia 27(1): 117-125.

Pelizza TR, Carvalho GL and Schuch MW (2010) growth evaluation of blueberry minicuttings under different growth regulators. Acta Horticulturae 884: 623-628.

Pelizza TR, Damiani CR, Rufato AR, Souza ALK, Ribeiro MF and Schuch MW (2011) Microestaquia em mirtileiro com diferentes porções do ramo e substratos. Bragantia 70(2): 319-324.

Peña MLP, Gubert C, Tagliani MC, Bueno PMC and Biasi LA (2012) Concentrações e formas de aplicação do ácido indolbutírico na propagação por estaquia dos mirtileiros cvs. Flórida e Clímax. Semina 33(1): 57-64.

Raseira MCB and Antunes LEC (2004) A cultura do mirtilo (Vaccinium myrtillus). Technical communication, 121. Embrapa Clima Temperado, Pelotas, 69 p.

Ristow NC, Carpenedo S and Antunes LEC (2010) Concentração foliar de nutrientes em mudas de mirtilo em função de diferentes substratos. Technical communication, 246. Embrapa Clima Temperado, Pelotas, 8 p.

Ristow NC, Antunes LEC and Carpenedo S (2012) Substratos para o enraizamento de microestacas de mirtileiro cultivar georgiagem. Revista Brasileira de Fruticultura 34(1): 262-268.

Santos AM and Raseira MCB (2002) Cultivo do mirtilo. Documents, 96. Embrapa Clima Temperado, Pelotas, 17 p.

Silva SR, Rodrigues KFD and Scarpare Filho JA (2011) Propagação de árvores frutíferas. USP/ESALQ/Casa do Produtor Rural, Piracicaba-SP, 63p.

Tonietto A, Fortes GRL and Silva JB (2001) Enraizamento de miniestacas de ameixeira. Revista Brasileira de Fruticultura 23(3): 636-646.

Trevisan R, Franzon RC, Fritsche Neto R, Gonçalves RS, Gonçalves ED and Antunes LEC (2008) Enraizamento de estacas herbáceas de mirtilo: influência da lesão na base e do ácido indolbutírico. Ciência e Agrotecnologia 32(2): 402-406.

Vignolo GK, Fischer JLO, Araujo VF, Kunde RJ and Antunes LEC (2012) Enraizamento de estacas lenhosas de três cultivares de mirtileiro com diferentes concentrações de AIB. Ciência Rural 42(5): 795-800.

Xavier A, Wendling I and Silva RL (2009) Silvicultura Clonal: princípios e técnicas. Editora UFV, Viçosa, 272p. 
Wilson PJ and Struve DK (2004) Overwinter mortality in stem cuttings. Journal of Horticultural Science and Biotechnology 79(6):842-849.

Yamamoto LY, Koyama R, Borges WFS, Antunes LEC, Assis AM and Roberto SR (2013) Substratos no enraizamento de estacas herbáceas de amora-preta Xavante. Ciência Rural 43(1): 15-20.

Received: July 05, 2017.

Accepted: October 24, 2017.

Published: February 12, 2018. 
